\title{
EFFECT OF CONFIGURATION ON LATERAL DISPLACEMENT AND COST OF THE STRUCTURE FOR HIGH RISE STEEL SPACE FRAMES SUBJECTED TO WIND LOADS
}

\author{
J.Renuka ${ }^{1}$, M. Pavan Kumar ${ }^{2}$ \\ ${ }^{1}$ M.E.Scholar, Civil engineering Department, S.V.P. engineering college, A.P, India \\ ${ }^{2}$ Asst.professor, Civil engineering Department, S.V.P. engineering college, A.P, India
}

\begin{abstract}
The choice of a cost effective lateral-force-resisting system for high-rise structures is challenging. There is no streamlined methodology to quantitatively compare the cost-effectiveness of each system beyond the more qualitative perception based evaluation of advantages or disadvantages. Developers currently base their decisions on architectural layout and structural integrity. Cost considerations are often primarily based on experience.

This decision making process has three primary shortfalls.

1) It may not incorporate factors which greatly affect the economy of a particular framing system.

2) It may not allow engineers to carryout designs at the least cost.

3) Comparison of framing systems may not address the specific building types.

This investigation proposes a prototype cost-effective model for selecting either a skeleton framing system or skeleton frame with bracing system for steel structural frames. A model for selecting cost-effective skeleton framing system or skeleton frame with bracing system will be a valuable tool for all decision makers. Engineers, in particular, will be able to select optimal steel framing faster, thus reducing design time and iterations. Furthermore, selection of economic framing system will also result in direct cost savings for steel structural frames.

The study involves the design and cost estimation of steel frames representing skeleton framing system and skeleton frame with bracingsystem. The cost effectiveness of the framing systems are compared based on lateral displacement requirements and cost.The preferred framing system should meet lateral displacement requirements and is lower in cost. The results of this pilot study showed that the Skelton framing system with bracing is the cost-effective choice for 30storeys steel space frames at wind speeds of $55 \mathrm{~m} / \mathrm{sec}, 50 \mathrm{~m} / \mathrm{sec}$ and $47 \mathrm{~m} / \mathrm{sec}$.
\end{abstract}

Keywords: Bracings, SFS (Skeleton framing system), SFWB (Skeleton frame with bracing system) etc...

\section{GENERAL ON TALL BUILDINGS}

High-rise structures have certain features. The structures are high \& lead to higher vertical loads and higher lateral loads in comparison with lower buildings. Buildings between 75 feet and 491 feet ( $23 \mathrm{~m}$ to $150 \mathrm{~m}$ ) high are the materials used for the structural system of high-rise buildings are reinforced concrete and steel

Vertical loads on the high rise structures have Dead loads arise from the weigh to the individual construction elements and the finishing loads and Live loads are dependent on use depending on the number of stories, live loads can be reduced for load transfer and the dimensioning of vertical load-bearing elements.

Horizontal LoadsCalculation of lateral loads should be carefully scrutinized. It generally arises from unexpected deflections, wind and earthquake loads
Unexpected Deflections arises from imprecision in the manufacture of construction elements and larger components, another cause is the uneven settling of the foundation at an in-homogeneous site.

Wind loadsHigh-rise buildings are susceptible to oscillation. It should not be viewed as statically equivalent loads, but must be investigated under the aspect of sway behavior. Wind tunnel experiments are used to see the influence of the building shape on the wind load. The ability of wind loads to bring a building to sway must also be kept in mind. This oscillation leads both to a perceptible lateral acceleration for occupants, and to a maximum lateral deflection

\subsection{Objectives of the Present Investigation:}

The aim of this thesis is therefore to make a comparative study of structural costs of high rise buildings designed with and without bracings. The study is to be restricted to a study of steel space frames only. 
Whether a building requires provision of bracings or not depends not only on the height of the building but also on the intensity of lateral loads. So it is proposed to carry out this comparison for different wind speeds of the country. i.e. $55 \mathrm{~m} / \mathrm{sec}, 50 \mathrm{~m} / \mathrm{sec}$ and $47 \mathrm{~m} / \mathrm{sec}$

Although principles for analysis of multi storied frames with bracings are quite well known, computer software packages are not readily available for carrying out such an analysis. Hence it is first necessary to develop efficient methods of analysis of framed buildings with bracings.

Hence the aims of the thesis are chosen as the following:

1. To select a "bench mark" structural configuration which could serve as the basis for comparative studies.

2. To develop a suitable method for analyzing multi storied frames with bracings interaction and establish its validity.

3 . To carry out analysis and design of the chosen building for heights of 30,60 , and $90 \mathrm{~m}$ to be constructed in various wind speeds $55 \mathrm{~m} / \mathrm{sec}, 50 \mathrm{~m} / \mathrm{sec}$ and $47 \mathrm{~m} / \mathrm{sec}$.

4. To make an analysis of the Displacement- values of the chosen high- rise buildings.

5. To obtain the total quantity of steel consumed for each of the examples studied and evaluate the efficiency or otherwise provision of bracings.

6. To provide guide lines for structural designers on the economies that could be obtained by using bracings.

\subsection{Scope of the Project:}

For the purpose of developing the Effectiveconfiguration framing system

1. The important factors are limited to lateral displacement and cost effectiveness subjected to wind loads

2. Designs are carried out using IS 800-1984

3. Cost comparison is done with respect to percentage variation in quantity of steel.

Here the study is primarily focused on a 30 storey structure representing skeleton framing system and skeleton frame with bracing systems. 10 and 20 storeys are also modeled and designed for cost comparison (with respect to quantity of steel) .This 30 storey structure is modeled in a plan area of $15 \mathrm{~m} \mathrm{x} \mathrm{40m} \mathrm{and} \mathrm{height} \mathrm{is} 90 \mathrm{~m}$ above G.L. with $3 \mathrm{~m}$ each floor level. For the analysis and design STAAD.Pro-2006 software is used.

\section{Codes used for design are:}

For Dead load IS: 875 (Part-I)

For Live load IS: 875 (Part-II)

For wind load IS: 875 (Part-III)

For Design IS: 800-1984

The dimensions of the building frame components are calculated by preliminary approximate approach and the dimensions are revised accordingly using STAAD.Pro-2006 software.

In case of steel space frames with bracings, thebracings are provided along the periphery of the structure.

\section{LITERATURE REVIEW}

Chaudhary ${ }^{1}$ et al Explained about India buildings which can be classified as tall buildings exist only in Mumbai and Delhi. Hence the literature available in Indian Journals on this topic is scarce. Some of the publications from Indian Journals are reviewed below. They presented in their paper, describing the basis for the selection of structural system and the corresponding analysis and design adopted for high-rise building (20 storeys). The principles involved in the selection of a structural system arc highlighted. The suitability of different structural system was discussed corresponding to the site chosen by them. Finally they selected shear wall core with space frame structural system to resist certain wind forces. They concluded that selection of a suitable system finally depends on necessary stiffness, strength and serviceability.

P. Jayachandran ${ }^{2}$ Explained about the design of tall buildings essentially involves a conceptual design, approximate analysis, preliminary design and optimization, to safely carry gravity and lateral loads. The design criteria are strength, serviceability, stability and human comfort. The strength is satisfied by limit stresses, while serviceability is satisfied by drift limits in the range of $\mathrm{H} / 500$ to $\mathrm{H} / 1000$. Stability is satisfied by sufficient factor of safety against buckling and P-Delta effects. The factor of safety is around 1.67 to 1.92 . The human comfort aspects are satisfied by accelerations in the range of 10 to 25 milli-g, where $\mathrm{g}=$ acceleration due to gravity, about $981 \mathrm{cms} / \mathrm{sec}^{\wedge} 2$. The aim of the structural engineer is to arrive at suitable structural schemes, to satisfy these criteria, and assess their structural weights in weight/unit area in square feet or square meters. This initiates structural drawings and specifications to enable construction engineers to proceed with fabrication and erection operations. The weight of steel in $\mathrm{lbs} / \mathrm{sqft}$ or in $\mathrm{kg} / \mathrm{sqm}$ is often a parameter the architects and construction managers are looking for from the structural engineer. This includes the weights of floor system, girders, braces and columns. The premium for wind, is optimized to yield drifts in the range of $\mathrm{H} / 500$, where $\mathrm{H}$ is the height of the tall building. Herein, some aspects of the design of gravity system, and the lateral system, are explored. Preliminary design and optimization steps are illustrated with examples of actual tall buildings designed by CBM Engineers, Houston, Texas, with whom the author has been associated with during the past 3 decades. Dr.JosephP.Colaco, its President, has been responsible for the tallest buildings in Los Angeles, Houston, St. Louis, Dallas, New Orleans, and Washington, D.C, and with the author in its design staff as a Senior Structural Engineer. Research in the development of approximate methods of analysis, and preliminary design and optimization, has been conducted at WPI, with several of the author's graduate students. 


\section{PROJECTMETHODOLOGY}

\subsection{Introduction}

This chapter presents the methodology adopted to evaluate the effective configuration among the skeleton framing system and skeleton frame with bracing systems for high rise building. The methodology includes analysis and design of the systems against different lateral loads followed by cost estimation. This chapter gives detailed description of the model considered for the framing system. For analysis and design, STAAD PRO- 2006 software is used. Cost estimation is done based on the quantities obtained from computer analysis. The steps involved in the methodology are:

- Basic model specifications.

- Modeling of skeleton framing system and skeleton frame with bracing system.

- $\quad$ Analysis and design.

- Cost estimation and comparison.

Basic model specification are first outlined as they describe the study variables and constants for the two framing system. For the purpose of simplicity, building type, floor system, floor area, bay size and column height remain constant through the study. However,numbers of stories and members sizes are varied. The next step examines modeling of the framing system and material specification. Analysis and design was done by working stress method using critical load combinations follows. This part mainly focuses on a 30 storey structure.

Cost estimation deals with the criteria for calculating quantity of steel for framing systems. The final step in the methodology outlines the comparison criteria which are the lateral displacement and steel cost. Lateral displacement of the framing systems are checked against code requirements. The preferred structural system must meet lateral displacement requirements as well as be lower in cost the governing parameter is lateral displacement.

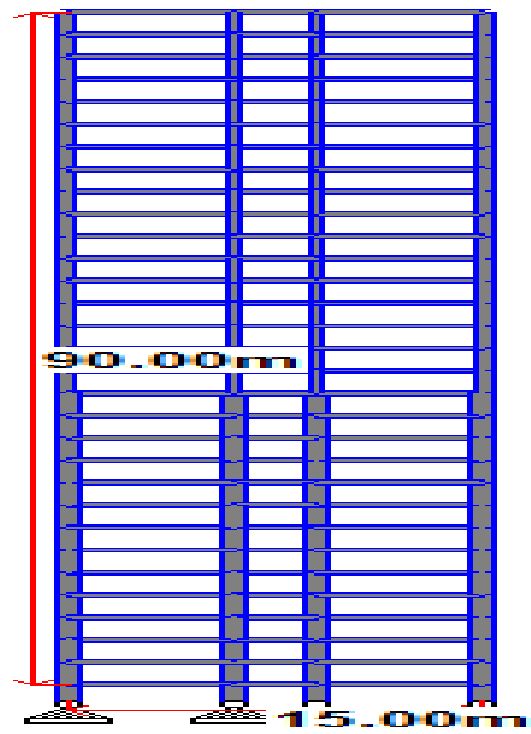

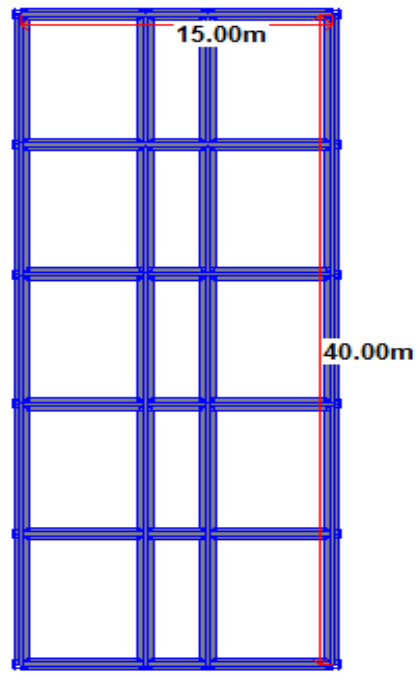

Fig: 3.1 Plan and elevation of 30 storey SFS
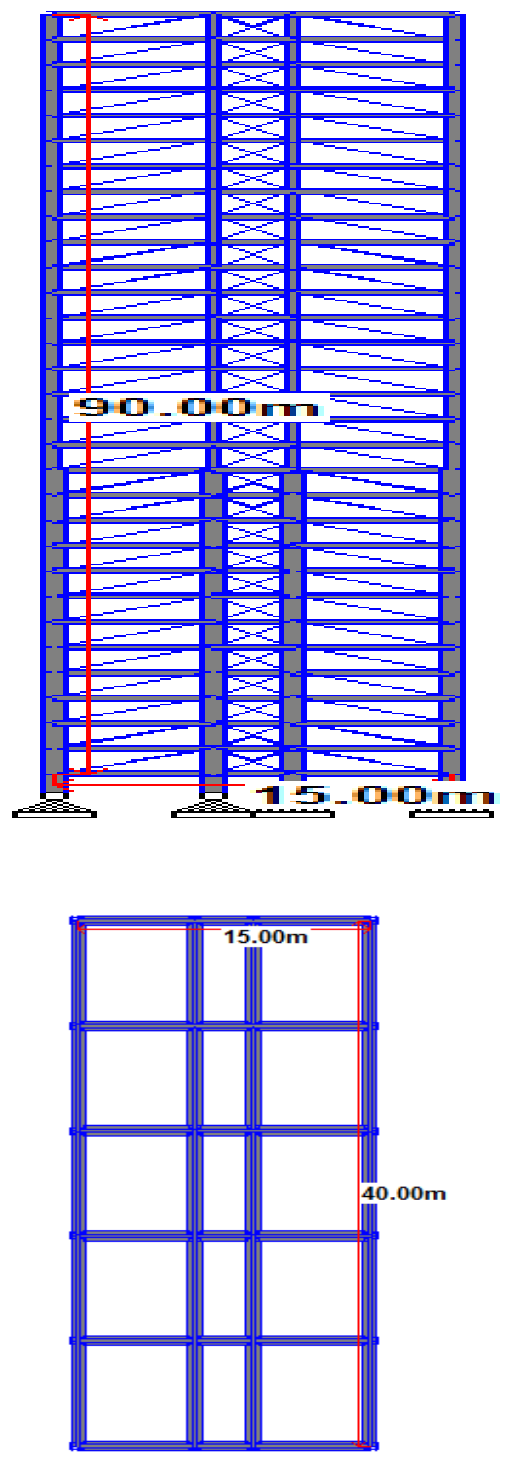

Fig: 3.2 Plan and elevation of 30 storey SFWB system 


\subsection{Loads Considered for the Design}

\subsubsection{Dead Load}

All the material weights as per IS: 875(Part-I)

\subsubsection{Live Load}

Design live load intensity was taken as $2 \mathrm{KN} / \mathrm{m}^{2}$ as per IS:875-II

\subsubsection{Wind Load: (IS 875- part- III)}

$\mathrm{V}_{\mathrm{b}}=$ basic wind speed i.e $55 \mathrm{~m} / \mathrm{sec}, 50 \mathrm{~m} / \mathrm{sec}$ and $47 \mathrm{~m} / \mathrm{sec}$

$\mathrm{V}_{\mathrm{z}}=$ design wind speed

$\mathrm{V}_{\mathrm{z}}=\mathrm{K}_{1}, \mathrm{~K}_{2} \mathrm{~K}_{3} \mathrm{~V}_{\mathrm{b}}$

$\mathrm{K}_{1}=$ Risk coefficient

$\mathrm{K}_{2}=$ Size, height and terrain factor

$\mathrm{K}_{3}=$ topography factor

Wind pressure $=0.6\left(\mathrm{~V}_{\mathrm{z}}\right)^{2}$

At $\mathrm{V}_{\mathrm{b}}=55 \mathrm{~m} / \mathrm{sec}$ for 30 - storey

$\mathrm{V}_{\mathrm{z}}=1 * 0.93 * 1 * 55=51.15 \mathrm{~m} / \mathrm{sec}, \mathrm{P}_{\mathrm{z}}=0.6\left(\mathrm{~V}_{\mathrm{z}}\right)^{2}=1.57 \mathrm{KN} / \mathrm{m}^{2}$ at $10 \mathrm{~m}$

$\mathrm{V}_{\mathrm{z}}=1 * 0.97 * 1 * 55=53.35 \mathrm{~m} / \mathrm{sec}, \mathrm{P}_{\mathrm{z}}=0.6\left(\mathrm{~V}_{\mathrm{z}}\right)^{2}=1.71 \mathrm{KN} / \mathrm{m}^{2}$ at

$15 \mathrm{~m}$

$\mathrm{V}_{\mathrm{z}}=1 * 1 * 1 * 55=55 \mathrm{~m} / \mathrm{sec}, \mathrm{P}_{\mathrm{z}}=0.6\left(\mathrm{~V}_{\mathrm{z}}\right)^{2}=1.81 \mathrm{KN} / \mathrm{m}^{2}$ at $20 \mathrm{~m}$

$\mathrm{V}_{\mathrm{z}}=1 * 1.04 * 1 * 55=57.2 \mathrm{~m} / \mathrm{sec}, \mathrm{P}_{\mathrm{z}}=0.6\left(\mathrm{~V}_{\mathrm{z}}\right)^{2}=1.96 \mathrm{KN} / \mathrm{m}^{2}$ at $30 \mathrm{~m}$

$\mathrm{V}_{\mathrm{z}}=1 * 1.10 * 1 * 55=60.5 \mathrm{~m} / \mathrm{sec}, \mathrm{P}_{\mathrm{z}}=0.6\left(\mathrm{~V}_{\mathrm{z}}\right)^{2}=2.19 \mathrm{KN} / \mathrm{m}^{2}$ at $50 \mathrm{~m}$

$\mathrm{V}_{\mathrm{z}}=1 * 1.17 * 1 * 55=64.35 \mathrm{~m} / \mathrm{sec}, \mathrm{P}_{\mathrm{z}}=0.6\left(\mathrm{~V}_{\mathrm{z}}\right)^{2}=2.48 \mathrm{KN} / \mathrm{m}^{2}$ at $100 \mathrm{~m}$

$\mathrm{V}_{\mathrm{z}}=1 * 1.21 * 1 * 55=66.55 \mathrm{~m} / \mathrm{sec}, \mathrm{P}_{\mathrm{z}}=0.6\left(\mathrm{~V}_{\mathrm{z}}\right)^{2}=2.66 \mathrm{KN} / \mathrm{m}^{2}$ at $150 \mathrm{~m}$

\subsection{Load Combinations Considered}

$1-\mathrm{DL}+\mathrm{LL}$

$2-(\mathrm{DL}+\mathrm{WLX})$

$3-(\mathrm{DL}+\mathrm{WL}(-\mathrm{X}))$

$4-(\mathrm{DL}+\mathrm{WLZ})$

$5-(\mathrm{DL}+\mathrm{WL}(-\mathrm{Z}))$

$6-0.75(\mathrm{DL}+\mathrm{LL}+\mathrm{WLX})$

$7-0.75(\mathrm{DL}+\mathrm{LL}+\mathrm{WL}(-\mathrm{X}))$

$8-0.75(\mathrm{DL}+\mathrm{LL}+\mathrm{WLZ})$

$9-0.75(\mathrm{DL}+\mathrm{LL}+\mathrm{WL}(-\mathrm{Z}))$

\subsection{Analysis and Design}

The structure with different framing systems has been modeled on STAAD PRO-2006 software with the above said load conditions and combinations. The analysis is done for both Skelton framing system and Skelton framing system with Bracing.

\subsubsection{Skelton Framing System:}

This comprises of columns and beams alone with support condition pinned. These columns and beams are created using beams elements of the software. Here instead of slab panels created, loads directly applied by software.

\subsubsection{Skeleton Frame with Bracing Systems}

This comprises of columns and beams as the framing systems, withbracings atperiphery of the frame.

\section{RESULTS \& DISCUSSIONS}

\subsection{General Consideration}

Comparison of lateral force resisting systems is done for each building category based on lateral loads, lateral displacement, material quantity and cost of structure. The building type is a multi storey structure with a $15 \mathrm{~m} \times 40 \mathrm{~m}$ plan area. Lateral force considered was windalone for basic wind speed $55 \mathrm{~m} / \mathrm{sec}, 50 \mathrm{~m} / \mathrm{sec}$ and $47 \mathrm{~m} / \mathrm{sec}$. Lateral displacement is checked against the requirements of IS:8001984 i.e. Under transient wind load the lateral deflection of the structure should not exceed $\mathrm{H} / 325$, where $\mathrm{H}$ is the total height of the structure. Cost of the framing system includes cost of columns, beamsand bracings (wherever bracings areused). The cost of foundation is not included. Findings are discussed below for 10, 20, 30 storey structures at basic wind speeds $55 \mathrm{~m} / \mathrm{sec}, 50 \mathrm{~m} / \mathrm{sec}$ and $47 \mathrm{~m} / \mathrm{sec}$.

\subsection{Comparison of Displacements for 30 Storey}

\section{Structure}

In order to ascertain the simplest yet reliable method for analyzing the combined action of frame plus bracings, the combined system has been analyzed for a load combination of DL+WL

The result from all these analysis are compared to find out their validity 


\section{LATERAL DISPLACEMENT FOR 30 STOREY WITH SFS \& SFWB}

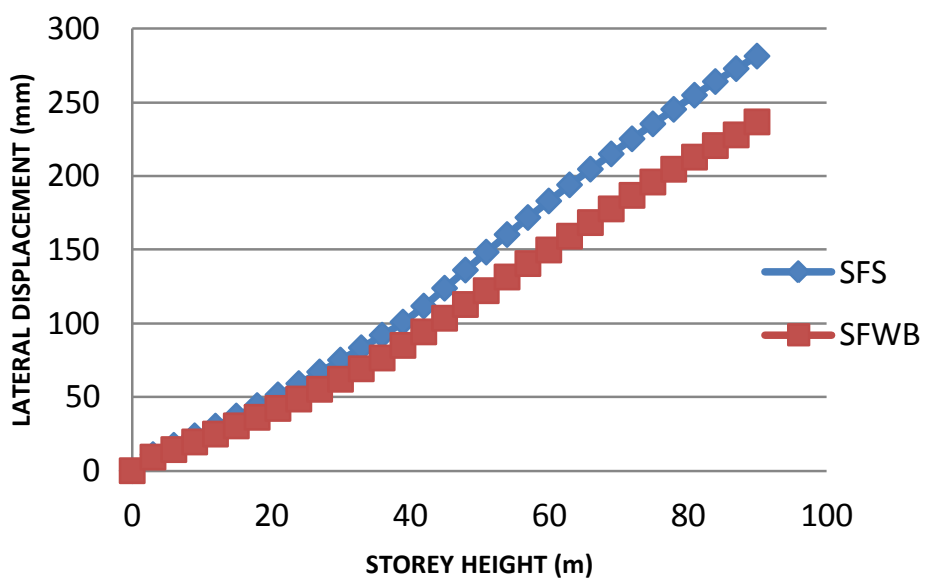

Fig: 4.1 Comparison of lateral displacement (WLX) for SFS and SFWB for basic wind speed $55 \mathrm{~m} / \mathrm{sec}$

From the figure 4.1, it is observed thatwhile comparing SFS with SFWB system, upto 18m (6 storeys) the lateral displacement due to wind load in X-direction are not considerable, beyond that there is a considerable amount of lateral displacement for wind speed of $55 \mathrm{~m} / \mathrm{sec}$.

Percentage of steel variation w.r.t S.F.S (30 STOREY)
\begin{tabular}{|l|l|l|l|}
\hline $\begin{array}{l}\text { WIND } \\
\text { SPEED } \\
(\mathrm{m} / \mathrm{sec})\end{array}$ & SFS & SFWB & $\begin{array}{l}\text { PERCENTA } \\
\text { GE } \\
\text { VARIATION }\end{array}$ \\
\hline 55 & 2043 & 2033 & 0.48 \\
\hline 50 & 1996 & 1982 & 0.7 \\
\hline 47 & 1966 & 1951 & 0.8 \\
\hline
\end{tabular}

\section{Lateral Displacement:}

30 -storey at basic wind speed $55 \mathrm{~m} / \mathrm{sec}$

The result for the lateral displacement for $55 \mathrm{~m} / \mathrm{sec}$ are presented in fig 4.7 The relation is shown between the lateral displacement for the two framing systems and the displacement limit which is $276 \mathrm{~mm}$ calculated from $\mathrm{H} / 325$ whereH is height of the structure. The lateral displacement for SF system is $281.39 \mathrm{~mm}$. While that of the skeleton framing with bracing system is $236.73 \mathrm{~mm}$. SFS exceeds permissible limit, so SFWB system is the effective configuration in terms of lateral displacement and cost effective.

\section{LATERAL DISPLACEMENT AT 55m/sec FOR 30 STOREY}

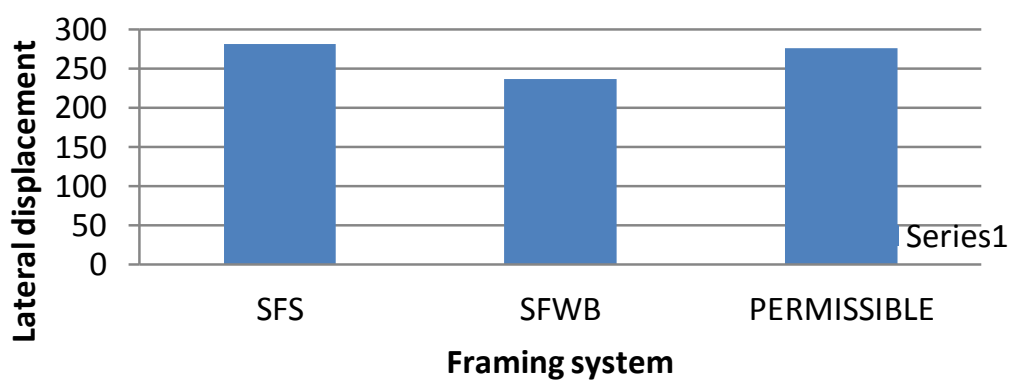

Fig: 4.2 Comparison of lateral displacement for SFS and SFWB with basic wind speed $55 \mathrm{~m} / \mathrm{sec}$ 
Material quantity: The SFWB system has about $0.48 \%$ reduction inpercentage of steel,is calculated as the difference in quantities divided by quantity used in the SFS multiplied by 100.

Weight of steel forvarious framing systems at different wind speeds are shown in table below:

Table: 4.1 Tonnage of steel required for SFS and SFWB (in Tonnes)

\begin{tabular}{|l|l|l|l|l|l|l|}
\hline $\begin{array}{l}\text { No of } \\
\text { storeys }\end{array}$ & $\begin{array}{l}\text { Tonnage of steel } \\
\text { obtained for } \\
55 \mathrm{~m} / \mathrm{sec}\end{array}$ & $\begin{array}{l}\text { Tonnage of steel } \\
\text { obtained for } \\
50 \mathrm{~m} / \mathrm{sec}\end{array}$ & $\begin{array}{l}\text { Tonnage of steel } \\
\text { obtained for } \\
47 \mathrm{~m} / \mathrm{sec}\end{array}$ \\
\hline & SFS & SFWB & SFS & SFWB & SFS & SFWB \\
\hline 30 & 2043 & 2033 & 1996 & 1982 & 1966 & 1951 \\
\hline
\end{tabular}

\subsection{Variation in Displacement for Basic Wind Speeds $55 \mathrm{~m} / \mathrm{sec}$, $50 \mathrm{~m} / \mathrm{sec}$ and $47 \mathrm{~m} / \mathrm{sec}$}

Variation $=$ Actual Displacement $/$ Allowable Displacement

For SFS \& SFWB, for basic wind speed $55 \mathrm{~m} / \mathrm{sec}$

Table 4.2: Variation in displacement for all storeys

\begin{tabular}{|l|l|l|l|l|l|}
\hline Storey & $\begin{array}{l}\text { SFS } \\
\text { Displacement } \\
(\mathrm{mm})\end{array}$ & $\begin{array}{l}\text { SFWB } \\
\text { Displacement } \\
(\mathrm{mm})\end{array}$ & $\begin{array}{l}\text { Allowable } \\
\text { Displacemen } \\
\mathrm{t}(\mathrm{mm})\end{array}$ & $\begin{array}{l}\text { SFS } \\
\text { Variation in } \\
\text { Displacement }\end{array}$ & $\begin{array}{l}\text { SFWB } \\
\text { Variation } \\
\text { Displacement }\end{array}$ \\
\hline 30 & 281.39 & 236.73 & 276 & 1.019 & 0.85 \\
\hline 20 & 123.345 & 105 & 184 & 0.67 & 0.57 \\
\hline 10 & 69.36 & 56.06 & 92 & 0.75 & 0.61 \\
\hline
\end{tabular}

\section{Variation in displacement, at wind speed $55 \mathrm{~m} / \mathrm{sec}$}

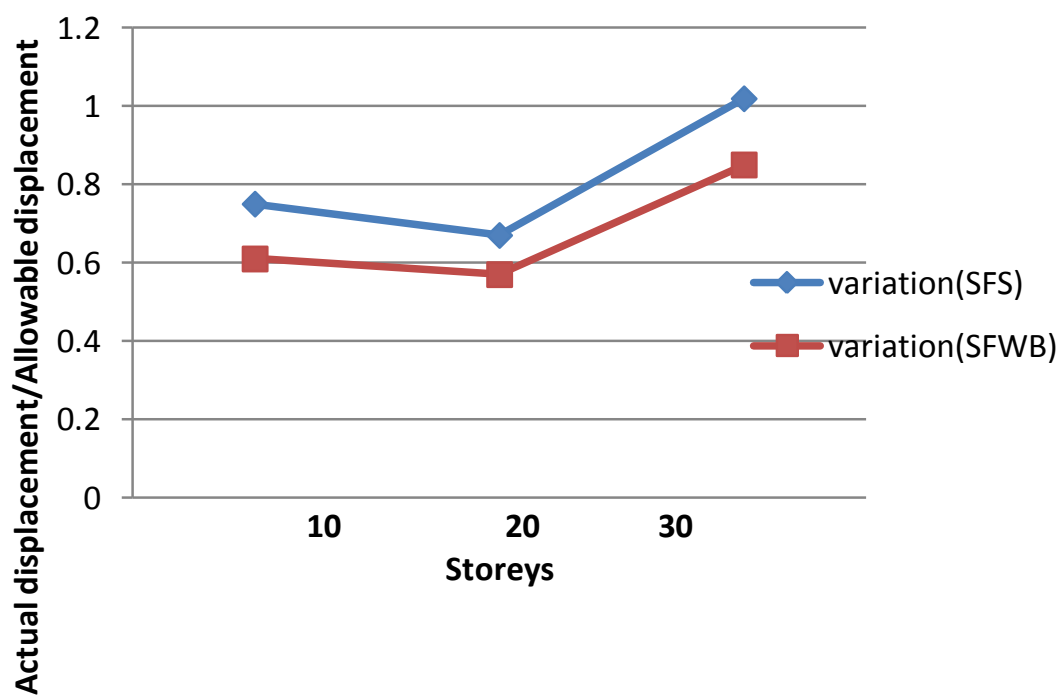

Fig 4.3: Comparison of displacement variation for the two systems, at wind speed $55 \mathrm{~m} / \mathrm{sec}$

For SFS \& SFWB, for basic wind speed $50 \mathrm{~m} / \mathrm{sec}$

Table 4.2: Variation in displacement for all storeys

\begin{tabular}{|c|c|c|c|c|c|}
\hline Storey & $\begin{array}{l}\text { SFS } \\
\text { Displacement } \\
(\mathrm{mm})\end{array}$ & $\begin{array}{l}\text { SFWB } \\
\text { Displacement } \\
(\mathrm{mm})\end{array}$ & $\begin{array}{l}\text { Allowable } \\
\text { Displacement } \\
(\mathrm{mm})\end{array}$ & $\begin{array}{l}\text { SFS } \\
\text { Variation in } \\
\text { Displacement }\end{array}$ & $\begin{array}{l}\text { SFWB } \\
\text { Variation } \\
\text { Displacement }\end{array}$ \\
\hline 30 & 252.11 & 211.08 & 276 & 0.91 & 0.76 \\
\hline 20 & 110.384 & 93.076 & 184 & 0.59 & 0.51 \\
\hline 10 & 67.90 & 54.01 & 92 & 0.73 & 0.58 \\
\hline
\end{tabular}




\section{Variation in displacement, at wind speed $50 \mathrm{~m} / \mathrm{sec}$}

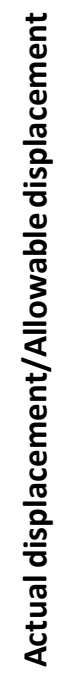

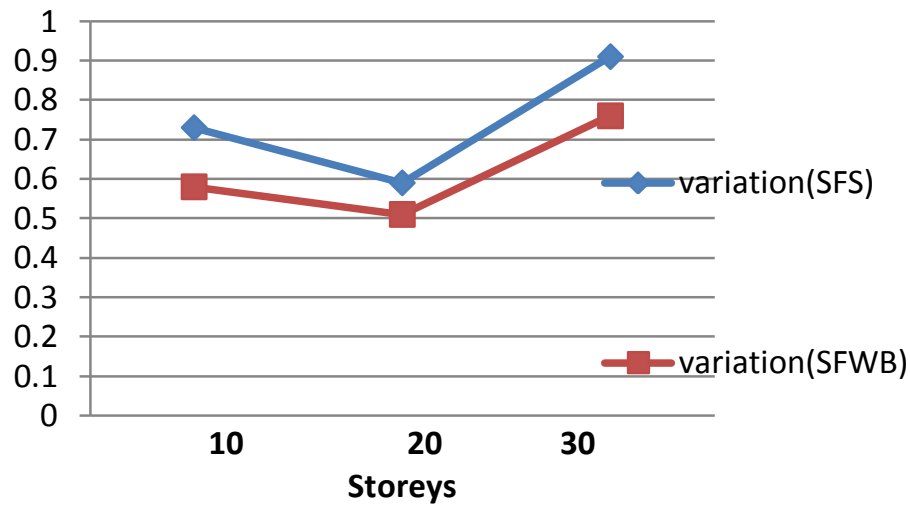

Fig4.4: Comparison of displacement variation for the two systems, wind speed $50 \mathrm{~m} / \mathrm{sec}$

For SFS \& SFWB, for basic wind speed $47 \mathrm{~m} / \mathrm{sec}$

Table 4.3: Variation in displacement for all storeys

\begin{tabular}{|l|l|l|l|l|l|}
\hline $\begin{array}{l}\text { Store } \\
\mathrm{y}\end{array}$ & $\begin{array}{l}\text { SFS } \\
\text { Displacement } \\
(\mathrm{mm})\end{array}$ & $\begin{array}{l}\text { SFWB } \\
\text { Displacement } \\
(\mathrm{mm})\end{array}$ & $\begin{array}{l}\text { Allowable } \\
\text { Displacement } \\
(\mathrm{mm})\end{array}$ & $\begin{array}{l}\text { SFS } \\
\text { Variation in in } \\
\text { Displacement }\end{array}$ & $\begin{array}{l}\text { SFWB } \\
\text { Variation in } \\
\text { Displacemen } \\
\mathrm{t}\end{array}$ \\
\hline 30 & 233.362 & 196.158 & 276 & 0.84 & 0.71 \\
\hline 20 & 102.328 & 86.362 & 184 & 0.56 & 0.47 \\
\hline 10 & 66.81 & 51.63 & 92 & 0.73 & 0.56 \\
\hline
\end{tabular}

\section{Variation in displacement, at wind speed $47 \mathrm{~m} / \mathrm{sec}$}
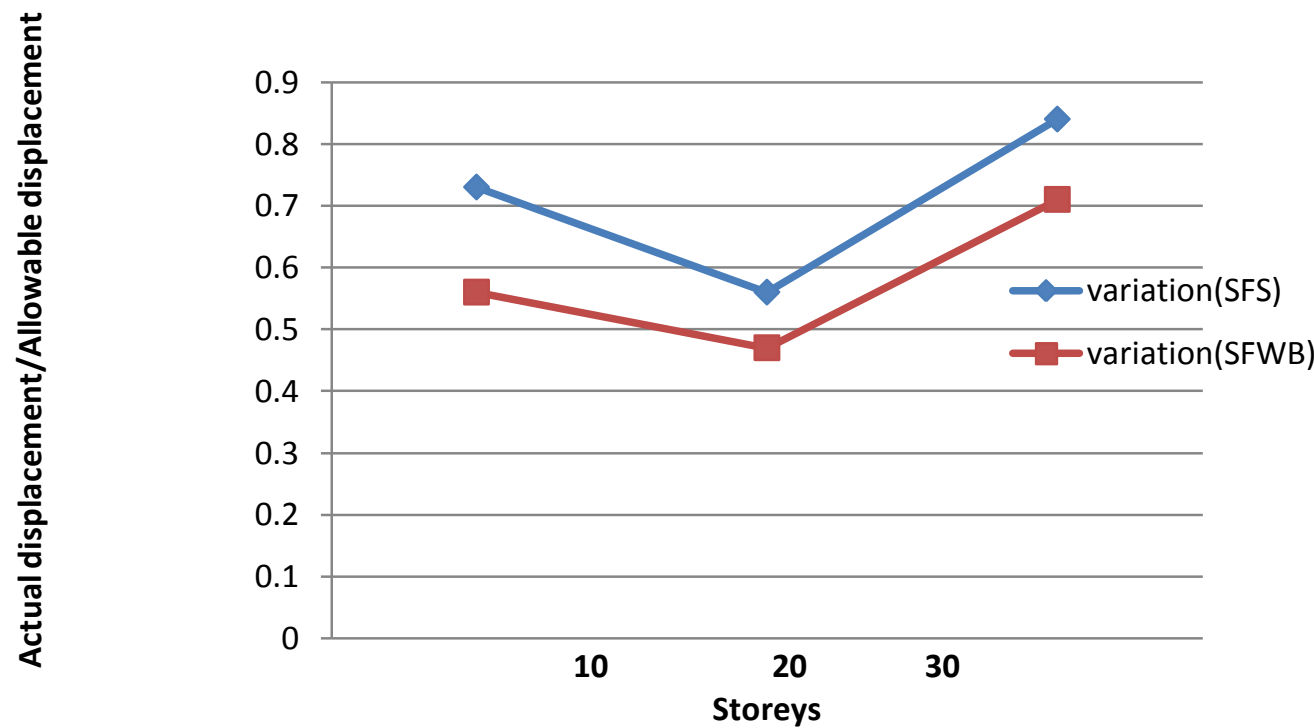

Fig4.6: Comparison of displacement variation for the two systems, wind speed $47 \mathrm{~m} / \mathrm{sec}$ 


\subsection{Comparison on Weight of Steel per Unit Area for the Two Systems}

For basic wind speed $55 \mathrm{~m} / \mathrm{sec}$ :

SFS:

Table- 4.5: weight/unit area, SFS

\begin{tabular}{|l|l|l|l|}
\hline Storey & $\begin{array}{l}\text { Total weight of } \\
\text { steel(tons) }\end{array}$ & $\begin{array}{l}\text { Total area } \\
\text { (sqm) }\end{array}$ & $\mathrm{Wt} / \mathrm{sq} \mathrm{m}\left(\mathrm{inKg} / \mathrm{m}^{2}\right)$ \\
\hline 30 & 2043 & 18000 & 113.5 \\
\hline 20 & 1258 & 12000 & 104.8 \\
\hline 10 & 303 & 6000 & 50.5 \\
\hline
\end{tabular}

SFWB:

Table- 4.6: weight/unit area, SFWB

\begin{tabular}{|l|l|l|l|}
\hline $\begin{array}{l}\text { Store } \\
\mathrm{y}\end{array}$ & $\begin{array}{l}\text { Total weight } \\
\text { of steel(tons) }\end{array}$ & $\begin{array}{l}\text { Total area } \\
(\mathrm{sqm})\end{array}$ & $\begin{array}{l}\mathrm{Wt} / \mathrm{sq} \\
\left(\mathrm{inKg} / \mathrm{m}^{2}\right)\end{array}$ \\
\hline 30 & 2033 & 18000 & 113 \\
\hline 20 & 1199 & 12000 & 100 \\
\hline 10 & 292 & 6000 & 48.7 \\
\hline
\end{tabular}

For basic wind speed $55 \mathrm{~m} / \mathrm{sec}$

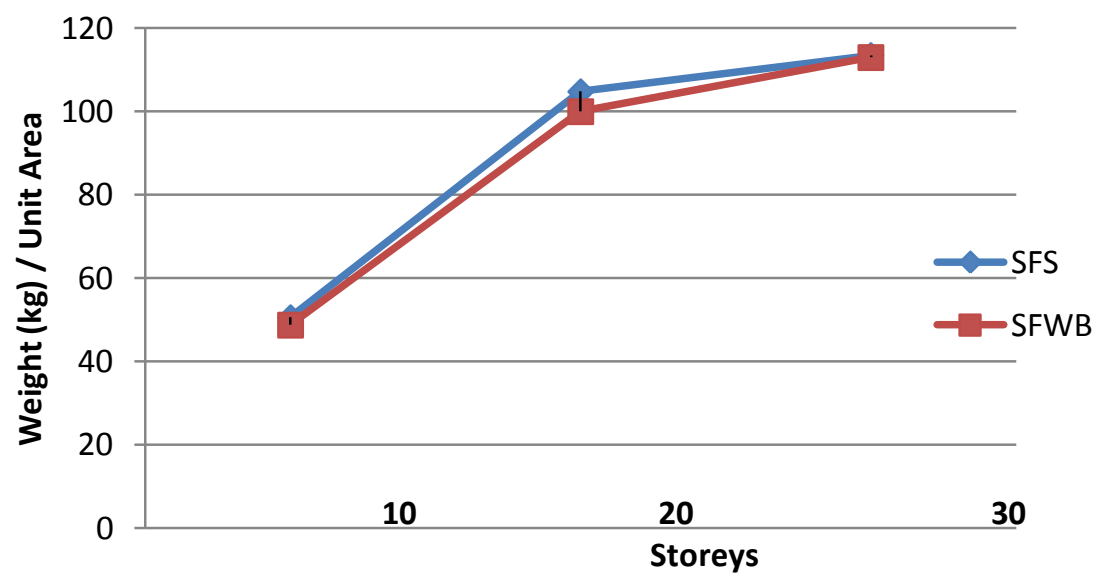

Fig4.7: Comparison of weight of steel for two systems, basic wind speed $55 \mathrm{~m} / \mathrm{sec}$

For basic wind speed $50 \mathrm{~m} / \mathrm{sec}$ :

SFS:

Table- 4.6: weight/unit area, SFS

\begin{tabular}{|l|l|l|l|}
\hline Storey & Total weight of steel(tons) & Total area $(\mathrm{sqm})$ & Wt/sq $\mathrm{m}\left(\mathrm{inKg} / \mathrm{m}^{2}\right)$ \\
\hline 30 & 1996 & 18000 & 111 \\
\hline 20 & 1243 & 12000 & 103.6 \\
\hline 10 & 289 & 6000 & 48.16 \\
\hline
\end{tabular}

SFWB:

Table- 4.7: weight/unit area, SFWB

\begin{tabular}{|l|l|l|l|}
\hline Storey & Total weight of steel(tons) & Total area $(\mathrm{sqm})$ & $\mathrm{Wt} / \mathrm{sq} \mathrm{m}\left(\mathrm{inKg} / \mathrm{m}^{2}\right)$ \\
\hline 30 & 1982 & 18000 & 110 \\
\hline 20 & 1175 & 12000 & 98 \\
\hline 10 & 281 & 6000 & 46.8 \\
\hline
\end{tabular}




\section{For basic wind speed $50 \mathrm{~m} / \mathrm{sec}$}

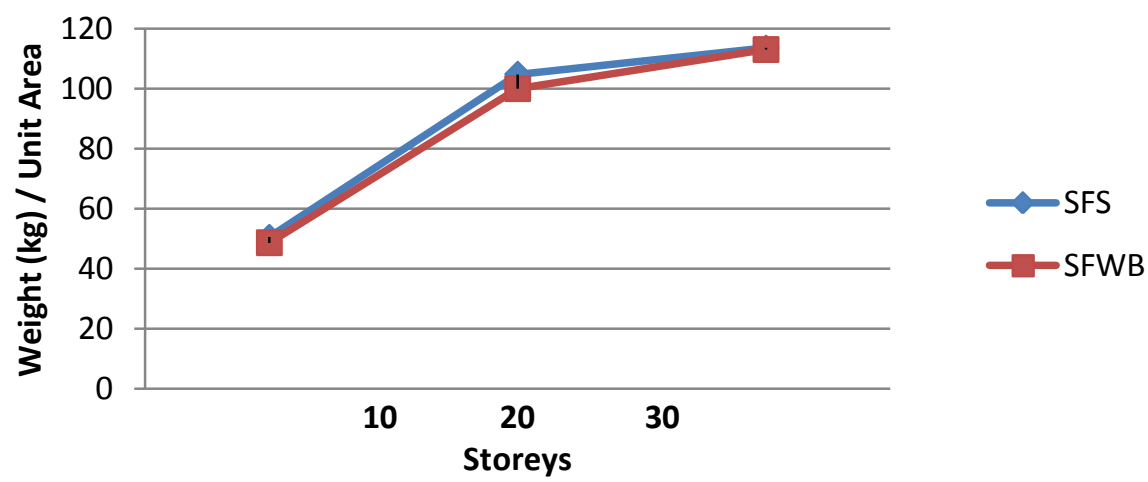

Fig4.8 Comparison of weight of steel for two systems, basic wind speed $50 \mathrm{~m} / \mathrm{sec}$

For basic wind speed $47 \mathrm{~m} / \mathrm{sec}$ :

SFS:

Table- 4.8: weight/unit area, SFS

\begin{tabular}{|l|l|l|l|}
\hline Storey & $\begin{array}{l}\text { Total weight of } \\
\text { steel(tons) }\end{array}$ & Total area $(\mathrm{sqm})$ & $\mathrm{Wt} / \mathrm{sq} \mathrm{m}\left(\mathrm{inKg} / \mathrm{m}^{2}\right)$ \\
\hline 30 & 1966 & 18000 & 109 \\
\hline 20 & 1235 & 12000 & 102.9 \\
\hline 10 & 280 & 6000 & 46.7 \\
\hline
\end{tabular}

SFWB:

Table- 4.9: weight/unit area, SFWB

\begin{tabular}{|l|l|l|l|}
\hline storey & $\begin{array}{l}\text { Total weight of } \\
\text { steel(tons) }\end{array}$ & Total area (sqm) & $\mathrm{Wt} / \mathrm{sq} \mathrm{m}\left(\mathrm{inKg} / \mathrm{m}^{2}\right)$ \\
\hline 30 & 1951 & 18000 & 108 \\
\hline 20 & 1164 & 12000 & 97 \\
\hline 10 & 277 & 6000 & 46.2 \\
\hline
\end{tabular}

For basic wind speed $47 \mathrm{~m} / \mathrm{sec}$

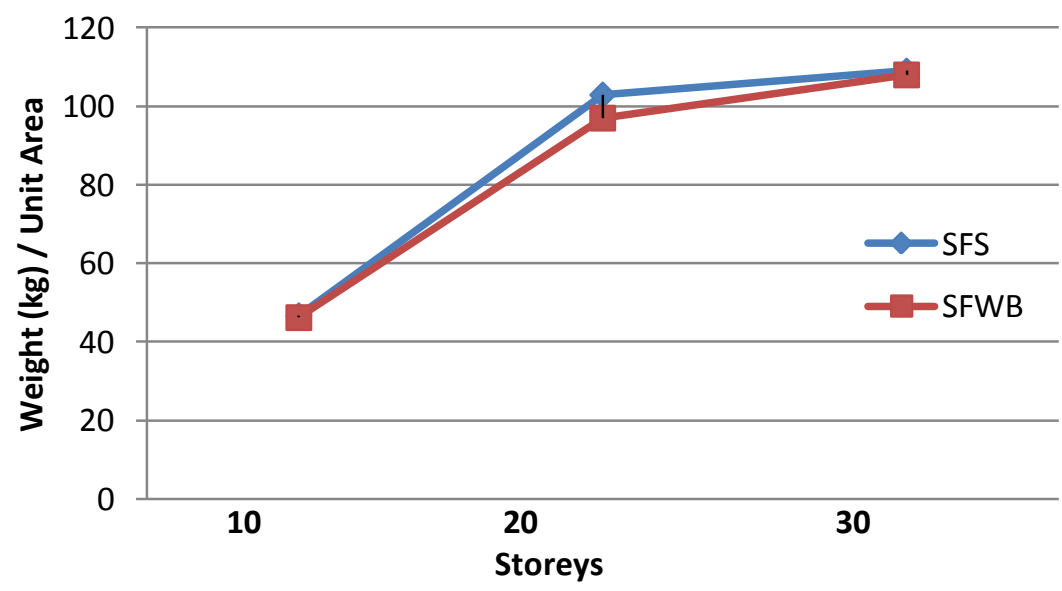

Fig: 4.9 Comparison of weight of steel of two systems, basic wind speed $50 \mathrm{~m} / \mathrm{sec}$ 


\subsection{Comparison of Cost per Unit Area for the Two systems}

Cost of steel per Metric Ton is taken as RS 48,000/- as per SSR-2011 September revision

For basic wind speed $55 \mathrm{~m} / \mathrm{sec}$ :

SFS:

SFWB:

Table- 4.10: Cost/unit area, SFS,

\begin{tabular}{|l|l|l|l|}
\hline Storey & $\begin{array}{l}\text { Total cost of } \\
\text { steel(rupees) }\end{array}$ & Total Area(sqm) & Cost/sqm \\
\hline 30 & $9,80,64,000$ & 18000 & 5448 \\
\hline 20 & $6,03,84,000$ & 12000 & 5032 \\
\hline 10 & $1,45,44,000$ & 6000 & 2424 \\
\hline
\end{tabular}

Table- 4.11: Cost/unit area, SFWB,

\begin{tabular}{|l|l|l|l|}
\hline Storey & $\begin{array}{l}\text { Total cost of } \\
\text { steel(rupees) }\end{array}$ & Total Area(sqm) & Cost/sqm \\
\hline 30 & $9,75,54,000$ & 18000 & 5419 \\
\hline 20 & $5,75,52,000$ & 12000 & 4796 \\
\hline 10 & $1,40,16,000$ & 6000 & 2336 \\
\hline
\end{tabular}

For basic wind speed $55 \mathrm{~m} / \mathrm{sec}$

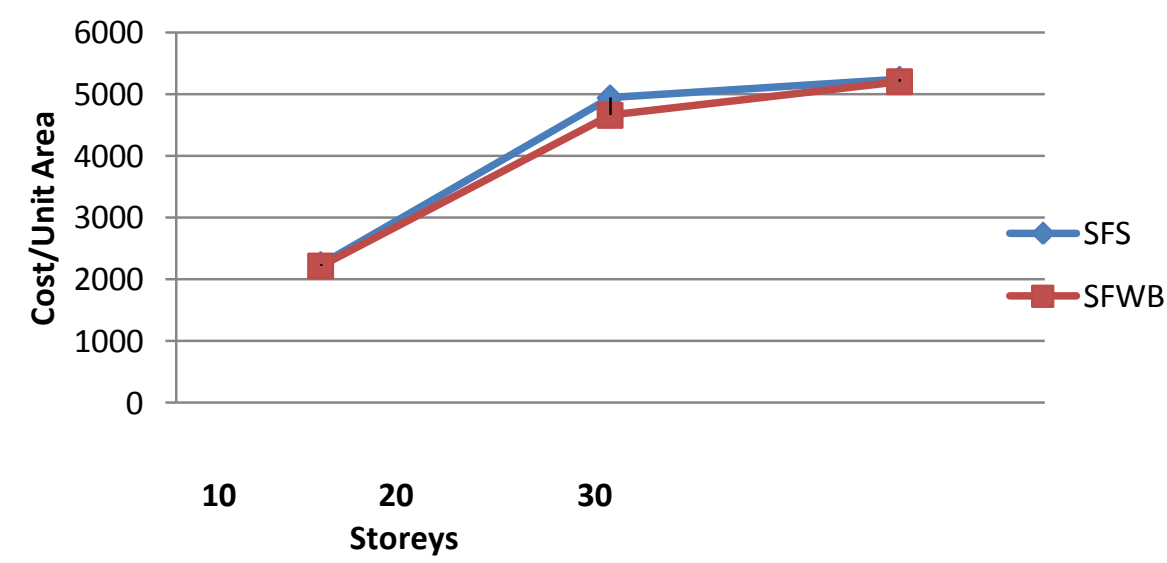

Fig: 4.10 comparison of cost/unit area for the two systems, $55 \mathrm{~m} / \mathrm{sec}$

For basic wind speed $50 \mathrm{~m} / \mathrm{sec}$ :

SFS:

Table- 4.12: Cost/unit area, SFS,

\begin{tabular}{|l|l|l|l|}
\hline Storey & $\begin{array}{l}\text { Total cost of } \\
\text { steel(rupees) }\end{array}$ & Total Area(sqm) & Cost/sqm \\
\hline 30 & $9,58,08,000$ & 18000 & 5322 \\
\hline 20 & $5,96,64,000$ & 12000 & 4972 \\
\hline 10 & $1,38,72,000$ & 6000 & 2312 \\
\hline
\end{tabular}




\section{SFWB:}

Table- 4.13: Cost/unit area, SFWB,

\begin{tabular}{|l|l|l|l|}
\hline Storey & $\begin{array}{l}\text { Total cost of } \\
\text { steel(rupees) }\end{array}$ & Total Area(sqm) & Cost/sqm \\
\hline 30 & $9,51,36,000$ & 18000 & 5,285 \\
\hline 20 & $5,64,00,000$ & 12000 & 4700 \\
\hline 10 & $1,34,88,000$ & 6000 & 2248 \\
\hline
\end{tabular}

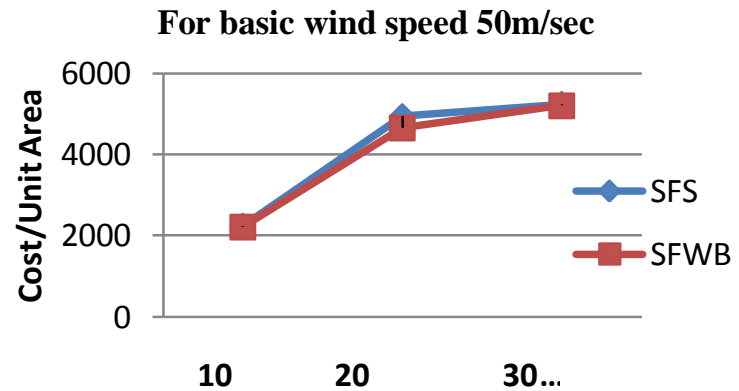

Fig: 4.11 comparison of cost/unit area for the two systems, $50 \mathrm{~m} / \mathrm{sec}$

For basic wind speed $47 \mathrm{~m} / \mathrm{sec}$ :

SFS:

Table- 4.14: Cost/unit area, SFS,

\begin{tabular}{|l|l|l|l|}
\hline storey & Total cost of steel(rupees) & Total Area(sqm) & Cost/sqm \\
\hline 30 & $9,43,68,000$ & 18000 & 5242 \\
\hline 20 & $5,92,80,000$ & 12000 & 4940 \\
\hline 10 & $1,34,40,000$ & 6000 & 2240 \\
\hline
\end{tabular}

\section{SFWB:}

Table- 4.15: Cost/unit area, SFWB,

\begin{tabular}{|l|l|l|l|}
\hline Storey & Total cost of steel(rupees) & Total Area(sqm) & Cost/sqm \\
\hline 30 & $9,36,48,000$ & 18000 & 5202 \\
\hline 20 & $5,58,72,000$ & 12000 & 4656 \\
\hline 10 & $1,32,96,000$ & 6000 & 2216 \\
\hline
\end{tabular}

For basic wind speed $47 \mathrm{~m} / \mathrm{sec}$
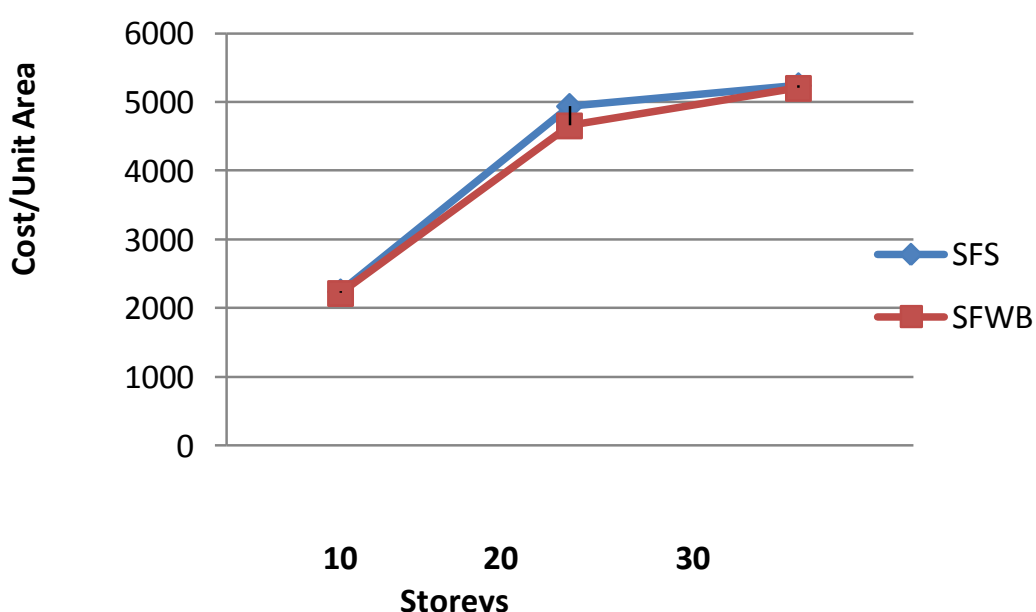

Fig: 4.12 comparison of cost/unit area for the two systems, $47 \mathrm{~m} / \mathrm{sec}$ 


\section{SUMMARY ANDCONCLUSIONS}

The major conclusions and recommendations are outlined below:

1. The concept of using steel bracing is one of the advantageous concepts which can be used to strengthen structure.

2. Steel bracings reduce flexure and shear demands on beams and columns and transfer the lateral load through axial load mechanism.

3. The lateral displacement of 10 storey structure reduced by $14 \%, 16 \%, 16 \%$ in SFWB system at considered wind speeds, i.e $55 \mathrm{~m} / \mathrm{sec}, 50 \mathrm{~m} / \mathrm{sec}$, and $47 \mathrm{~m} / \mathrm{sec}$ respectively. In all considered cases the lateral displacement in SFS and SFWB systems are within the permissible limit.

4. The lateral displacement of 20 storey structure reduced by $19 \%, 21 \%, 23 \%$ in SFWB system at considered wind speeds, i.e $55 \mathrm{~m} / \mathrm{sec}, 50 \mathrm{~m} / \mathrm{sec}$, and $47 \mathrm{~m} / \mathrm{sec}$ respectively. In all considered cases the lateral displacement in SFS and SFWB systems are within the permissible limit.

5. The lateral displacement of 30 storey structure reduced by $16 \%$ in SFWB system at all considered wind speeds,i.e $55 \mathrm{~m} / \mathrm{sec}, 50 \mathrm{~m} / \mathrm{sec}$, and $47 \mathrm{~m} / \mathrm{sec}$ respectively. In all considered wind speeds of 30 storey structure the lateral displacement in SFS and SFWB systems are with in the permissible limit,but in the case of basic wind speed $55 \mathrm{~m} / \mathrm{sec}$, observed that SFS exceeds the permissible limit (i.e $\mathrm{H} / 325$ ), where as SFWB system is within the permissible limit. So we strongly recommended SFWB system at $55 \mathrm{~m} / \mathrm{sec}$ in the view of requirement of lateral displacement.

6. While comparing the cost of the structure, in all the considered cases we concluded that there is a less margin of percentage of variation of cost. Whereas, the margin in percentage of variation of cost was low, but it should also meet lateral displacement criteria.

7. While comparing lateral displacements of 10, 20 and 30 storey of SFS at wind speeds of $50 \mathrm{~m} / \mathrm{sec}$ and $47 \mathrm{~m} / \mathrm{sec}$ with 10, 20 and 30 stories SFWB system, observed that there is a considerable reduction in the lateral displacement at wind speed of $55 \mathrm{~m} / \mathrm{sec}$.

8 . From the study, concluded that for 30 storey structurethe SFWB system will be the effective in configuration (i.e.; both lateral displacement and cost) subjected to wind loads.

\section{SUGGESTIONS FOR FUTURE WORK}

1. Because of time constraints the study in this particular theory was restricted to the comparison of weight of super structure in different systems. A more meaningful comparison will be to compute the total cost of the structure.i.e. Both super structure and sub structure.

2. It will be interesting to carry out similar studies for severe seismic zones also.

3. A more meaningful study will be to analyze and design connections and their quantity.

\section{REFERENCES}

[1] ALPD SHETH and R.D.CHAUDHARY ."Innovative integration of space frame and framed tube for high rise buildings...(2004)ICJ. Vol. 78,.No.5 . Page: 13-I8.

[2] AshishS.Agrawal, S.D.Charkha, 2012, "Effect of change in shear wall location on storey drift of multi storey buildings subjected to lateral loads", International Journal of Engineering Research and Applications, May-June 2012, Volume 2, No 3 , pp 1786-1793

[3] Dr. Barry Davidson, 2007, "Response of multi storey buildings", Proceedings of India- Newzealand work shop on Seismic design of RCC structures organized by ICI at IIT Madras in March 20-21, 2007

[4] CLIVE L. DYM, F.ASCE, P.E. and HARRY E. WILLIAMS "Technicalnoteson fundamental frequency of tall buildings" (2006) Journal of Structural Engineering / Volume 133 / Issue 10

[5] E. Miranda, and S. D. Akkar, 2006, "Generalized Inter story Drift Spectrum”, ASCE, 2006, pp 733 745

[6] GARY R. SEARER and SIGMUND A. FREEMAN "design drift requirements for long-period structures" 13th World Conference on Earthquake Engineering, (2004), Paper No. 3292

[7] HyoSeon Park, Ji Hyun Seo, Yun Han Kwon, 2007, "Development of drift design model for high-rise buildings subjected to lateral and vertical loads", Article first publishedonline, 2007

[8] Md. Asheque Al Mahbub, Ishtiaque Ahmed,2000, "Influence of structural parameters on scaling factor for site specific response spectrum", Journal of Civil Engineering, The Institution of Engineers Bangladesh, 2000 Volume CE 28, No 1

[9] P.Jayachandran, "Design of Tall Building Preliminary Design and optimization" Worcester polytechnic, Institute,01609,U.S.A National workshop on high rise and tall buildings, University of Hyderabad, May 2009, Keynote lecture.

[10] P. M. Pradhan, P. L. Pradhan, R. K. Maskey, 2012, "A Review on partial in filled frames under lateral loads" , Katmandu University Journal of science, Engineering and technology , February 2012, Volume 8, No 1, pp 142-152

[11] Romy Mohan, C. Prabha, 2011, "Dynamic analysis of RCC buildings with shear wall”, International Journal of Earth Sciences and Engineering, Volume 04, No 06 SPL, October 2011, pp 659-662.

[12] Serdarcarbas, oguzhanhasancebi " Optimum Design of steel space frames via Bat Inspired Algoritham” Department of Civil Engineering Middle East Technical University ,Turkey. $10^{\text {th }}$ World Congress on structural and multi disciplinaryOptimization, may 19-24,2013, Orlando, Florida, U.S.A.

[13] Shailendra Kumar Dubey, Sunil Kute “ An investigation on the minimizing captive column effect by using steel bracing" Department of Civil Engineering, S.S.V.P.SBSD College of Engineering. 
Dhule, (M.S ) India, ACE Volume 1,Issue 1 Oct 2013 PP. 23-26

[14] S.K.MADAN, "Design forces for coupling beams of shear walls subjected to seismic forces"(2006) ICJ,Vol. 80. No.11.

[15] S.M.Dhawade\&P.S.Pajgade "Consideration of seismic design of multistoried steel structures" Department of Civil Engineering prof. Ram Meghe college of engineering, Badnena-Amravathi , International journal of civil Engineering Research,ISSN 2278-3652 volume 5, number 2(2014),pp177-182.

[16] S.S.YADAV. -“Computer Aided Analysis, Design and Estimation of Multi storied Buildings"-( 1999) ICJ. Vol.73. No.2

[17] S.R.UMA and A.MEHER PRASAD "Seismic behaviour of beam -column joints in R.C Momentresisting frames" (2006)A review. ICJ. Vol. 86. -, No.1

[18] Trevor E. Kelly, 2008, "Improving seismic performance: add stiffness or damping?" Bulletin of Newzealand Society of Earth quake Engineering, March 2008, volume 41 No 1, pp 24-30

[19] IS: 800-1984, Steel Design, Code of Practice

[20] Indian standard Codes of Practice for Design Loads(other than Earthquake) for Buildings and Structures -Dead Loads IS 875 (part-I): 1987, Bureau of Indian Standards, New Delhi.

[21] Indian standard Codes of Practice for Design Loads(other than Earthquake) for buildings and Structures - Imposed Loads IS 875 (part-II): 1987, Bureau of Indian Standards, New Delhi

[22] Indian standard Codes of Practice for Design Loads(other than Earthquake) for Buildings and Structures - Wind Loads IS 875 (part-III): 1987, Bureau of Indian Standards, New Delhi.

[23] Indian standard Codes of Practice for Design Loads (other than Earthquake) for Buildings and Structures - Special Loads and Combinations IS 875 (part-V): 1987, Bureau of Indian Standards, New Delhi. 